\title{
Exploring the Relationship Between Foreign Language Anxiety, Gender, Years of Learning English and Learners' Oral English Achievement Amongst Chinese College Students
}

\author{
Hualan $\operatorname{Tan}^{1} \&$ Zhilong Xie ${ }^{1}$ \\ ${ }^{1}$ School of Foreign Languages, Jiangxi Normal University, Nanchang, China \\ Correspondence: Hualan Tan, 99\#Ziyang Road, Jiangxi Normal University, Nanchang, Jiangxi Province, China. \\ E-mail:767315089@qq.com
}

Received: April 15, 2020 Accepted: May 18, 2020 Online Published: June 23, 2020

doi:10.5539/ells.v10n3p31 URL: https://doi.org/10.5539/ells.v10n3p31

\begin{abstract}
English serves as a bridge of communication for the people from all over the world as it plays an increasingly crucial role in the process of globalization. In accordance with English curriculum standards issued by the Ministry of Education in 2011, the ultimate goal of English language discipline is to communicate. But over these years, China's English education has been difficult to get out of the dilemma of "Dumb English". When facing the real oral communication situations, students are still too nervous to speak with a great deal of fluency and accuracy. Therefore, the present study aims to explore the relationship between English language anxiety, gender, years of English learning and final oral English achievement by inviting 41 English major freshmen of foreign language departments of Nanchang Business College. For this purpose, this study adopts a reliable Foreign Language Classroom Anxiety Scale developed by Horwitz and Cope (1986) to measure students' anxiety. The results reveal that anxiety levels between males and females are similar; there is also no significant difference among years of learning English; however, a significantly negative correlation between college students' foreign language anxiety and their oral English learning achievement was found.
\end{abstract}

Keywords: foreign language classroom anxiety, learning achievement, oral English learning

\section{Introduction}

Emotional variables are regarded as one of the important indexes in the new English curriculum standard in China. Anxiety which provides a new direction for oral English teaching in English teaching is the most important emotional factor in English learning and teaching. Numerous studies have shown that spoken language anxiety in the process of learning foreign language is very common (Walter, 1975; Selvam et al., 2016), especially in China, which might be related to Chinese traditional culture. Recently, there has been a great deal of foreign language anxiety in the field of pedagogy and psychology (Horwitz et al., 1986; Suleimenova, 2013; Kayikçi, 2011; Durmuş, 2018), since the foreign language anxiety is one of the crucial psychological factors. Moreover, due to the individual differences of participants and environmental factors on foreign language anxiety and learning achievement, gender and other factors, there is no consensual view regarding the relationship between foreign language anxiety and learning achievement, gender and other potential factors (Chastain, 1975; Yashima, 2002; Suleimenova, 2013). Thus, the current study aims to figure out the relationship between foreign language anxiety, gender, years of learning English and learners' learning achievement.

\section{Literature Review}

\subsection{Definition of Foreign Language Anxiety}

It was Frued who first defined anxiety as "something felt", an emotional state that included feelings of apprehension, tension and nervousness, accompanied by physiological arousal (Freud, 1936). Frued initially noticed anxiety and suggested that it had a major impact on people's daily lives. From the perspective of Spielberger and Gorsuch, anxiety can be conceptualized and measured as either a trait anxiety, state anxiety, or situation-specific anxiety in SLA (Spielberger et al., 1970).

In terms of the foreign language anxiety, Horwitz (1986) and colleagues conceptualized the foreign language anxiety as "a quite complex of one's beliefs, feelings, and behaviors and self-perceptions that be correlative with 
language learning during the language learning processes" (Horwitz \& Cope, 1986). The Foreign Language Classroom Anxiety (FLCAS) was also developed by Horwitz with the purposes of capturing learners' specific anxiety reaction toward the process of foreign language learning. In addition, Horwitz and associates conceptualized foreign classroom language anxiety by integrating communication apprehension, test anxiety and fear of negative evaluation.

According to the conclusions made by previous studies, the situation-specific anxiety that is closely related to apprehension is unique to specific situations, which have aroused wide attention in SLA (Walter, 1975; Selvam, 2016).

\subsection{Theoretical Foundations}

\subsubsection{Affective Filter Hypothesis}

It was Krashen who developed the affective filter hypothesis in the 1980s. From the perspective of Krashen, emotional variables such as anxiety, self-confidence, self-esteem and motivation were closely associated with second-language acquisition. More importantly, he regards this affective factor as a filter which may promote or inhibit language input in the process of language learning. In addition, the positive or negative attitude of language learners toward language learning will directly affect the acquisition of language input. If learners established a weak affective filter in the way of possessing high self-confidence, beliefs, and moderate anxiety, then the language learning process will speed up obviously.

\subsection{Previous Related Research Studies}

Since the 1970s, foreign scholars (Gardner, 1994; Sellers, 2000) have done much research on this field with the purpose of having a deeper understanding of the anxiety in the process of foreign language learning. Before the 1980 s, the study results on the relationship between language anxiety and learning achievement is confusing. Some scholars believed that foreign language anxiety is not conducive to learners' foreign language learning process, while others have come to the opposite conclusions. For example, Chastain (1975) investigated the relationship between anxiety and language learning achievements in three different languages: French, German, and Spanish. In French audio-visual class, test anxiety has a significant negative effect on the French grade. That is to say, Students with lower anxiety tend to get better grades than higher ones.

While Backman (1976) showed that there is no significant correlation between teachers' ratings in a listening comprehension test with the anxiety measures, Backman proved that Venezuelan students' progress was measured by a listening comprehension test. From above research, we can find that the results on the relationship between foreign language anxiety and learning achievement are mixed. Probably, the main reason for this outcome was the lack of standard foreign language anxiety measurement scale.

With the birth of the Foreign Language Classroom Anxiety Scale (FLCAS), (Horwitz \& Cope) in 1986, and the research conclusions on FCLAS beginning to become unified. Most researchers (Kitano, 2001; Zhang \& Liu, 2006; Ebrahimi, 2013) in home and abroad have shown that foreign language anxiety has significantly negative effects on the process of foreign language learning. Some scholars are investigating the relationship between anxiety and foreign language achievement in a general way, while others explored the relationship between one kind of specific anxiety (i.e., anxiety in listening, speaking, reading or writing) and foreign language achievement in a specific way.

\subsubsection{The Relationship Between Learning Achievement and Language Anxiety in General Aspect}

Horwitz et al. (1986) adopted the Foreign Language Classroom Anxiety (FLCA) Questionnaire, they studied the relationship between academic achievement and foreign language anxiety and found that there was significantly negative correlation between each other. That is Spanish and French students with higher foreign language anxiety tended to receive lower course grades than students with lower anxiety. Likewise, a study conducted by Gardner in 1994 reveals that language anxiety is inversely related to achievement in grades seven, nine, and eleven. Consistent with the previous studies on the relationship between foreign language classroom anxiety and students' overall English achievement (Chen \& Zhang, 2004), a significant negative correlation between the external classroom anxiety of 54 college English students who are not in English major and their total English achievement was found.

However, Backman's (1976) study suggests no association between language anxiety and achievement, surprisingly, the two lowest ability subjects had the highest and the lowest anxiety scores. In addition, some researchers have attempted to delineate clusters of variables that would define language learning variables (Yashima, 2002; Sila, 2010), and links between anxiety and achievement have been examined. By studying the relationships between affective variables and students' final grades, Samimy and Tabuse (1992) found that 
different variables influenced students' performance at different times. In their study, variables affecting student performance changed over time, with gender, risk-taking (affected by anxiety), and the status (undergraduate or graduate) being the important predictors of students' achievements in the first term.

Most studies on the relationship between foreign language anxiety and language learning achievement at home and abroad tend to reach a consensus, that is, foreign language anxiety has a significantly negative effect on students' language learning acquisition. However, most studies only be limited in studying from a general and broad perspective, instead of focusing on one kind of specific foreign language ability, such as speaking, listening, reading and writing. It is still worthwhile a further discussion in the relationship between the language anxiety and one specific foreign language ability.

\subsubsection{The Relationship Between Learning Achievement and Language Anxiety in Specific Aspect}

In addition to that general classroom language anxiety study, learners are likely to have different degree of anxiety in listening, speaking, reading, writing these specific aspects in SLA, which refers to "Situation Specific Anxietes". For instance, Sellers (2000) also investigated the foreign language anxiety's effect on reading comprehension. The results reported that higher the level of reading anxiety, the worse the college students' recall of Spanish texts, and the lower reading anxiety behave better. While take the non-English major university students as participants the result isn't different (Zhang \& Liu, 2006). The similar findings also be found in writing grade (Cheng, Horwitz, \& Schallert, 1999) and listening achievement (Wang, 2010).

Accumulating studies had conducted the effect of FLA in students' oral achievement. For example, using FLCAS, Kitano (2001) invited 212 college students to finish the questionnaire, and then measure their anxiety in the process of learning spoken Japanese. The results revealed that the degree of students' oral anxiety was in decisive proportion to their negative evaluation anxiety and their low evaluation of self-target language ability. Wei (2010) also proved that the college students' anxiety level in English class has adverse effect on the fluency of spoken language. Subsequently, Suleimenova (2013) also showed that debilitative effect on students' speaking achievements has been found. Because anxious students tend to suffer from 'mental block' and feel incapable, which result in learners forgetting words and phrases that they want to speak. Likewise, in Ebrahimi (2013) study, speaking anxiety be regarded as a detrimental factor by inviting 100 students at an Iran university with ten years history of learning English. The final result reported that most participants are likely to become nervous while speaking English in front of others, and some of them be worried when they lack full preparation, half of them are feel inferior to others, and the rest were nervous unconsciously when open mouth to speak English.

Despite ample studies have advocated that language learning performance negatively affected by students' FLA, others also suggest the benefits of FLA. For instance, Selvam et al. (2016) hold the view that FLA is of great significance in assisting students learn more from their deficiencies in the process of learning FL. To prove their beliefs, they took 100 EFL students as the research subjects. Surprisingly, the result found that learners who identified with moderate speaking anxiety are more thirst in learning from their failures, and then be more likely to perform better in oral English. In addition, study conducted by Pong (2010) aims to figure out whether facilitative or debilitative effect exists in speaking anxiety. 32 EFL students of a Taiwan university were required to hand in their speech' videos. The findings reported that the students tend to prepare better and practice more in video than in a direct and authentic communication activity.

\subsubsection{The Relationship Between Gender, Years of Learning English and Language Anxiety}

Ample evidence shows that language anxiety among female students and male students are similar. Take the study conducted by Shi and Liu (2006), for example, 211 sophomore students who major in Non-English joined in. The results are, compared with female students' reading anxiety, male students' anxiety in reading was significantly higher, and their English learning achievement is quite lower subsequently, but no significant difference in gender was discovered in language classroom anxiety. Inconsistent with most research findings in this field, some studies also noted that significant difference was found between sex and language anxiety (Gardner, 1985; Kayikçi, 2011).

Apart from gender, years studying English also be taken into account while exploring the effect on language anxiety in this field. More attention paid to figure out whether the learning history would be an important predictor of measuring the language anxiety. Generally speaking, most of us will think that the longer they learn English, the less anxiety they have, because of the improvement on their integrated abilities and the accumulation of their English learning experience. In contrast to the common belief, Rezazadeh and Travokoli (2009) has claimed that no meaningful correlation between test anxiety and the time spent in studying the language was found. However, Sila (2010) held the view that individual's cognitive ability tend to change over 
time, significant difference between a child, adolescent and adult learner in cognitive styles and learning ability. To date, the research conducted by Durmuş and associates (2018), suggested that there is no correlation between anxiety in speaking Turkish and students' age, gender, years studying Turkish. Given that there is no consensus on the relationships between gender, years of learning English and language anxiety, further research on this issue is worthwhile. Although previous results in most studies agreed that there is negative correlation between foreign language learning anxiety and learning achievement, the existing research merely focuses on one language anxiety and the language ability achievement alone, ignoring some relevant covariates that may affect the language acquisition achievement, such as participant's age, gender, years of learning English and so on.

\section{Method}

\subsection{Research Questions}

The main purpose of this study is to explore the relationships between English language anxiety, gender, years of learning English and final oral English achievement. Thus, the current study will focus on the following questions:

1) Is there any correlation between college students' foreign language anxiety and their oral English learning achievement?

2) Is there any significant difference between the higher and lower language anxiety among males and females?

3) Is there any correlation between years of learning English and oral English learning achievement among college students?

\subsection{Research Hypotheses}

Based on the previous relative studies, the following research hypotheses be made:

(1) There is significantly negative effect on oral English achievement between high language anxiety group and low language anxiety group.

(2) There is a significant difference between the higher and lower language anxiety among males and females.

(3) There is no correlation between years of learning English and oral English learning achievement.

\subsection{Data Collection}

\subsubsection{Participants}

In the summer of 2019, freshmen who major in English at the Nanchang Business College were invited to participate in this study. There are 22 male and 19 female participants in this study. The forty-one participants with a mean age of 19.24 years, and they have been learning English about 10 years so far. Actually, four students' data in this class has been ticked out, because they didn't attend class regularly and failed some crucial exams. Thus, only 41 students' data were used for the final analysis.

\subsubsection{Research Instruments}

\subsubsection{Questionnaire Survey}

The FLCAS questionnaire that contains thirty-three items was adopted in this study. The reliability (Cronbach's alpha $=0.93$ ) of FLCAS confirmed by studying 300 students who are introductory undergraduate foreign language classes at the University of Texas, and test-retest reliability $r=.83, p=.001, n=78.1$. All the participants are required to answer the questions with a 5-point Likert scale, rating their answers from (a) "strongly disagree", to (e) "strongly agree". If student's answer is (a) "strongly disagree", then score one point, and (e) "strongly agree" score five points. When statements of the FLCAS were negatively worded, responses were reversed and recorded. Before using the questionnaire, the reliability and validity testified. In addition, some background information mainly including some personal questions, like the student's age, sex and years of learning English also be collected.

\subsubsection{Oral English Grade}

The oral achievement consists of usual performance and final speech performance. And the usual performance consists of class attendance, classroom presentation and the oral class assignments. Most importantly, the final oral score gained by randomly choosing one topic from three topics, and then students were asked to give a speech around the topic that they got for nearly 2 minutes. By taking the fluency of oral presentations and accuracy of pronunciation and body language of each students into account. Each student's oral grade is strictly scored by two oral teachers, then the average score of two teachers be regarded as the student's final exam oral performance. 


\subsubsection{Data Collection and Analysis}

Participants were asked to fill in a FLCAS questionnaire and offer some supplementary background information (i.e., name, gender, year of learning English) on the questionnaire in the fall semester 2019. Before handing out the questionnaires, informing students of some requirements and purpose of the questionnaire survey. First of all, the subject is asked to fill in the name number, gender, age and contact information before formally answering the questionnaire. Then to guarantee all the information is only used for scientific research and their personal information would be protected well, so as to ensure the authenticity and reliability of these data.

Then, to record the final oral English scores that consists of usual performance and final oral exam. Each student's oral performance is strictly scored by two oral teachers, the average score of two teachers as the student's final exam oral performance. Finally, enter the anxiety scores and the oral English grade into the form, and then start to analyze the data by using SPSS (16.0).

To study the relationship between English language anxiety, gender, years of learning English and final oral English achievement, the following quantitative research methods will be used. Firstly, Descriptive Statistics used to analyze the mean and standard deviation of anxiety among Males and females in this study. Secondly, Pearson Correlation adopted to reveal the correlation between participants' grade, sex, learning years and anxiety. Lastly, Three-Way ANOVA was conducted to figure out the main effect and interaction effect between English language anxiety, gender, years of learning.

\section{Results}

\subsection{Gender Differences of Foreign Language Classroom Anxiety}

The present study, using 41 students of English major.From Table 1, the mean $(X=95.8)$, standard deviation $($ s.d. $=16.91)$, and range obtained in this study were very similar to those of Horwitz (Horwitz \& Young, 1991), who took students in an introductory Spanish class as research subjects, It reported the mean anxiety is 95.8. Compared with Horwitz's study, $X=94.5$, which was slightly higher. The possible explanation for this is that learning English is more likely to be anxious than learning Spanish. In the present study, no significant gender difference was found in language anxiety: $\mathrm{F}(1,20)=.405, \mathrm{p}=.532, \mathrm{p}>.05$. The mean score among males $(\mathrm{n}=$ $22)$ is 91.68 (s.d. $=17.69)$, while females $(\mathrm{n}=19)$ is 100.58 (s.d. $=15.03)$. It confirmed that the FLCAS is a reliable tool to measure foreign language anxiety.

Table 1. Descriptive statics

\begin{tabular}{llll}
\hline \multicolumn{4}{l}{ The Mean and Standard Deviation of Anxiety among Males and Females $(\mathrm{N}=41)$} \\
\hline \multicolumn{3}{l}{ Males $(\mathrm{N}=22)$} & Females $(\mathrm{N}=19)$ \\
Mean $(\mathrm{M})$ & Standard Deviation $(\mathrm{SD})$ & Mean $(\mathrm{M})$ & Standard Deviation $(\mathrm{SD})$ \\
91.68 & 17.69 & 100.58 & 15.03 \\
Total $(\mathrm{N}=41)$ & & 95.8 & 16.91 \\
\hline
\end{tabular}

Table 2. Pearson correlation between participants' grade, sex, learning years and anxiety $(\mathrm{N}=41)$

\begin{tabular}{lll}
\hline Grade & Correlation & -.287 \\
& Sig.(2-tailed) & .069 \\
Sex & Correlation & .222 \\
& Sig.(2-tailed) & .163 \\
Learning Years & Correlation & -.212 \\
& Sig.(2-tailed) & $\mathbf{. 1 8 3}$ \\
\hline
\end{tabular}

\subsection{The Correlations Between Foreign Language Anxiety and Students' Performance, Sex and Learning Years}

In the following analysis, the relationship between students' foreign language anxiety and learning performance was figured out (see Table 2). Firstly, using a Pearson product-moment correlation, the correlation coefficient between language anxiety and oral English achievement was obtained. The result showed a moderate negative correlation $(r=-.287)$ between the two, which suggesting that students with higher anxiety tend to perform worse in English learning than the lower ones.

As for the second analysis, first of all, students were divided into a higher anxiety group or a lower anxiety group in line with students' average anxiety scores. According to the result revealed in Table 1, we can see the mean anxiety for this sample was 95.8. Thus, in this study, if student's anxiety scores higher than 96, then the student 
would be regarded as the high-level anxiety. If lower than 95, then the student would be regarded as the low-level anxiety.

Three-way ANOVA conducted. Result showed that there was a significant main effect of anxiety: $\mathrm{F}(1,69)=$ $5.044, \mathrm{p}<.01$ (see Table 3). In this sense, we can draw the conclusion that the higher anxiety group received significantly lower oral grades $(X=89)$ than the lower one $(X=90.1)$. However, no significant effect of gender and years of learning English on final oral grade was discovered: $F(1,69)=1.205, p=.285, p>.05$. $F(1,69)=$ $1.424, \mathrm{p}=.255, \mathrm{p}>.05$, respectively. This result is similar with the research conducted by Durmuş and associates (2018), in which implied that there is no correlation between anxiety in speaking Turkish and students' age, gender, years studying Turkish and so on.

Table 3. Anxiety by sex by learning years ANOVA results on oral achievement $(\mathrm{N}=41)$

\begin{tabular}{llllll}
\hline Source & Sum of Squares & df & Mean Squares & F & Sig. of F \\
\hline Main Effect & & & & & \\
Anxiety & 17.452 & 1 & 17.452 & 5.044 & $\mathbf{. 0 3 6}$ \\
Sex & 4.168 & 1 & 4.168 & 1.205 & .285 \\
Learning Years & 29.555 & 6 & 4.926 & 1.424 & .255 \\
Interaction & & & & & .405 \\
Sex by anxiety & 1.402 & 1 & 1.402 & .891 & .483 \\
Learning Years by Anxiety & 12.327 & 4 & 3.082 & \\
\hline
\end{tabular}

\section{Discussion}

The current study investigated whether the foreign language anxiety of freshmen major in English has adverse effect on their oral English scores, and examines the relationship between students' foreign language anxiety and their sex and years of learning English. The final findings are similar with other research using Western languages like French, German, and Spanish, that is language anxiety was negatively related to students' performance in oral English, which means students with higher language anxiety have lower scores in oral English exam.

However, in this study, there is no significant difference among sex. That is to say, the anxiety level between males and females is not significant, which is inconsistent with most of research (Kayikçi, 2011; Shi \& Liu, 2006). A possible explanation for this opposite result is that the 41 male participants of English major come from two different classes, instead of the same class. Due to the different the class atmosphere and environment in class one and class two, the anxiety degree of the boys might be greatly varying.

In addition, the result also showed there is no significant difference between foreign language anxiety and the years of learning English, which disagree with what most research have reported. Thus, whether learning history could be a significantly potential predictor of English learning performance among college students needs further discussion. In this study, the reason why the results differ from previous studies may be that the research data only limited in first-year students in English major and most of them have about ten years history in learning history. In line with what suggested by Samimy and Tabuse (1992), whether determining variables would change over time or not. In this sense, if taking the sophomore or junior students as the subjects, the effect on language anxiety might be significant.

Given that language anxiety tend to contribute to adverse effect during the process of learning English, some insightful suggestions are extremely necessary. Firstly, teachers should be sensitive enough to notice and discover whether students have language anxiety or not, and then creating a friendly atmosphere to reduce the pressure in making mistakes in front of students and teachers. As we known, the teacher who is good at identifying students' inner problems and providing corresponding solutions to release their anxiety will be more popular. Moreover, teachers need to response to the students' needs both in study and psychology immediately, and give students enough trust and security in foreign English classroom to encourage them to show and share themselves in English. Finally, it is necessary for teachers to strengthen communication with students, to care about students' individual emotional factors in the process of learning English, and try their best to help students to improve their self-confidence and self-esteem in speaking English.

\section{Conclusion}

The current study mainly uses questionnaire designed by Horwitz (1986) to examine the relationship between language of oral English anxiety in freshmen major in English and final oral English learning achievement, 
gender and years of learning English. Pearson correlation and three-way ANOVA adopted. And then the following conclusions be made: (1) there is a significant negative correlation between language anxiety and learning achievement. That is to say, compared with higher foreign class language anxiety, students with lower foreign class language anxiety tend to have better oral English learning achievement. A possible explanation for the different results may be the participants of males come from two classes; different class has different class atmosphere and environment. (2) There is no significant difference between the higher and lower language anxiety on males and females, which is inconsistent with previous research findings. (3) There is also no significant difference between years of learning English and oral English learning achievement college students, which reaches the same conclusion with other researches in home and abroad.

\section{Limitations and Suggestions for Further Research}

Although the results of this study are consistent with the most studies' findings (Wang, 2010; Kitano, 2001; Kayikçi, 2011; Suleimenova, 2013), some limitations of this study should not be ignored. First of all, the subjects in this study were only those freshmen who major in English and have been learning English around ten years. If the subjects replaced by non-English majors and studied English for longer years, then the research results might be quite different. Due to the teaching courses and teaching objectives of college students vary from different grades, the students' anxiety degree may change over time, and finally affect the results of the study. There is no denying that third-year students are more likely to be required to speak in a more challenging situation in daily reading or writing classes. All these higher-level speaking practices have a tendency to improve students' oral proficiency. As for freshmen, more attention paid to develop four comprehensive skills. In addition, students' individual experiences or proficiency haven't been taken into account.

Secondly, given that boys in English major class are few, the participants of boys are not taken from the same class, while the females belong to the same class, which is not precise. In addition, although the Foreign Language Classroom Anxiety Scale is the most widely used tool, there is still no specific and suitable foreign language spoken anxiety scale. Thus, it is worthwhile a further exploration on the foreign language spoken anxiety scale.

Lastly, there still lack of the research novelty. Obviously, most research mainly focuses on the correlation between language anxiety and the final exam grade, instead of other emotional factors. Therefore, future research should be directed towards exploring the potential relationship between anxiety and other psychological variables in English learning, like learners' beliefs, self-esteem, risk-taking (Christopher, 1986), learning styles and personality (Lavine, 1990; Swain \& Barbara, 1976).

\section{References}

Backman, N. (1976). Two Measures of Affective Factors as They Relate to Progress in Adult Second Language Learning. Working Papers in Bilingualism, 10, 100-122.

Chastain, K. (1975). Affective and Ability Factors in Second Language Acquisition. Language Learning, 25, 153-161. https://doi.org/10.1111/j.1467-1770.1975.tb00115.x

Chen, X. L., \& Zhang, M. (2004). Foreign Language Anxiety and Students' Achievements of College-English. Journal of Chongqing University (Social Sciences Edition), 5(10),114-117.

Cheng, Y. S., Horwitz, E. K., \& Schaller, D. L. (1999). Language anxiety: differentiating writing and speaking components. Language Learning, 49(3), 417-446. https://doi.org/10.1111/0023-8333.00095

Christopher, E. (1986). An Analysis of Discomfort, Risk-taking, Sociability, and Motivation in the L2 Classroom. Language Learning, 36, 1-25. https://doi.org/10.1111/j.1467-1770.1986.tb00366.x

Durmuş, K., Cemal, O., \& Nuri, B. (2018). In-class and out-of-class anxiety in Speaking Turkish as a Second Language. Problems of Education in the 21st Century, 6(76), 816-833. https://doi.org/10.33225/pec/18.76.816

Ebrahimi, R. (2013). Anxiety as deterring element in learning English for oral communication among EFL students. International Journal of Applied Language Learning and Applied Linguistics World, 4(3), $136-143$.

Freud, S. (1936). The problem of anxiety. New York: Norton Press.

Gardner, R. C. (1985). Social psychology and second language learning: The role of attitudes and motivation. London: Edward Arnold Press.

Gardner, R. C., \& MacIntyre, P. D. (1994). The Subtle Effects of Language Anxiety on Cognitive Processing in 
the Second Language. Language Learning, 2(44), 283-305. https://doi.org/10.1111/1467-9922.00227

Horwitz, E. K. (1986). Preliminary Evidence for the Reliability and Validity of a Foreign Language Anxiety Scale. Teachers of English to Speakers of Other Languages, 3(20), 559-562. https://doi.org/10.2307/3586302

Horwitz, E. K., \& Cope, J. (1986). Foreign Language Classroom Anxiety. The Modern Language Journal, 70(2), 125-132. https://doi.org/10.1111/j.1540-4781.1986.tb05256.x

Kayikçi, K. (2011). A Conceptual Framework on Managing Student Misbehaviors and a Research in Primary Schools in Turkey. Journal of Education Research, 2(5), 119-142.

Kitano, K. (2001). Anxiety in the College Japanese Language Classroom. The Modern Language Journal, 4(85), 549-566. https://doi.org/10.1111/0026-7902.00125

Krashen, S. D. (1981). The "Fundamental Pedagogical Principle" in Second Language Teaching. Studia Linguisica, 35, 50-70. https://doi.org/10.1111/j.1467-9582.1981.tb00701.x

Pong, K. (2010). Learners' anxieties on posting their own speeches on Youtube.com: Facilitative or Debilitative? In selected papers from the Third Conference on College English. College English: Issues and Trends, 3, 73-100.

Rezazadeh, M., \& Tavakoli, M. (2009). Investigating the Relationship among Test Anxiety, Gender, Academic Achievement and Years of Study: A Case of Iranian EFL University Students. English Language Teaching, 2(4), 68-74. https://doi.org/10.5539/elt.v2n4p68

Samimy, K. K., \& Tabuse, M. (1992). Affective Variables and a Less Commonly Taught Language: A Study in Beginning Japanese Classes. Language Learning, 3(42), 377-398. https://doi.org/10.1111/j.1467-1770.1992.tb01341.x

Sellers, V. D. (2000). Anxiety and reading comprehension in Spanish as a foreign language. Foreign Language Annals, 33(5), 512-521. https://doi.org/10.1111/j.1944-9720.2000.tb01995.x

Selvam, P., Mohd, E., Swaminathan, V., \& Baskaran, S. (2016). Effects of debilitative and facilitative anxiety on speaking in second language among Malaysian ESL learners (pp. 1-20). Modern Language Association Annual Meeting.

Shi, Y. Z., \& Liu, Z. Q. (2006). The Relationship between Foreign Language Reading Anxiety and English Achievement and Gender. Journal of the PLA Institute of Foreign Languages, 2(29), 59-64.

Spielberger, C. D., Gorsuch, R. L., \& Lushene, R. E. (Eds.). (1970). The State-Trait Anxiety Inventory. California: Consulting Psychologists Press.

Suleimenova, Z. (2013). Speaking anxiety in a foreign language classroom in Kazakhstan. Social and Behavioral Sciences, 93, 1860-1868. https://doi.org/10.1016/j.sbspro.2013.10.131

Walter. H. B. (1975). A Study of the Relationship of Certain Learner Factors with the Ability to Communicate in a Second Language (German) for the Development of Measures of Communicative Competence (pp. 48-52). Doctoral dissertation, Ohio State University, Graduate School, Dissertation Abstracts International.

Wang, Y. P. (2010). A Study on English Listening Anxiety and Learning Strategies among Non-English Majors. Journal of Wuhan Ship Vocational and Technical College, 60-62.

Wei, W. X. (2010). Research on Classroom Anxiety of College Spoken English and Its Enlightenment for Teaching (p. 94). Doctoral dissertation, Southwest Normal University, Dissertation Abstracts International.

Yashima, T. (2002). Willingness to Communicate in a Second Language: The Japanese EFL Context. The Modern Language Journal, 3, 55-60. https://doi.org/10.1111/1540-4781.00136

\section{Copyrights}

Copyright for this article is retained by the author, with first publication rights granted to the journal.

This is an open-access article distributed under the terms and conditions of the Creative Commons Attribution license (http://creativecommons.org/licenses/by/4.0/). 